of malfunction. Here it overlaps with otology on one hand and education or rehabilitation on the other.

In the face of such a wide coverage of topics, it is perhaps ungracious to ask for more, but the inclusion of binaural hearing and speech audiometry as separate topics would have been welcomed. It is true that both subjects are mentioned in different chapters where their inclusion is appropriate, but specific contributions in these two fields would have been useful in view of the fact that both are essential matters of study for audiologists and developments in both have boen very considerable.

The work, however, is warmly commended to all interested in audiological problems. Each reader will have his own specific interests and may not wish to make too close an acquaintance with every topic discussed, and yet it is difficult to see how ignorance of any of these developments is compatible with good clinical or experimental work. It should serve as a standard reference work for some years to $\operatorname{come}$, and the very full list of references at the end of each chapter enhances its value for this purpose.

T. J. WATSON

\section{BRITISH MAMMALS RECORDED}

The Handbook of British Mammals

Edited for the Mammal Society by H. N. Southern. Pp. $\mathrm{xxi}+465+60$ photographs. (Oxford: Blackwell Scientific Publications, 1964.) 37s. 6d. net.

$\mathrm{T}$ HE study of mammals in Britain has only ever had the support of a rather small, though ardent band of naturalists. Yet with remarkable regularity, once every few decades, their accumulated knowledge erupts into a great work on British mammals. The first ordering of scattered information was undertaken by Thomas Bell in his History of British Quadrupeds, Including the Cetacea, published by Van Voorst in 1837. His list of indigenous terrestrial mammals stood slightly short of our present list, but was diversified by the inclusion of an oared shrew Sorex remifer, a beech martin, and three species of hares. There were no introduced species to describe except the long-established fallow deer, rabbit and rats, and a third of the book was devoted to domestic animals. Thirty-seven years later, in 1874, Bell, with the assistance of Tomes and Alston, completely revised the book. The Irish hare was now seen as a variety of the mountain hare, the oared shrew had gone, and several species of bats had lost their identity. Neither Darwin's new ideas nor the theory of the transformation of species were mentioned, but the woodcut of the former and rather sad-looking Sorex remifer had been transferred to become a vignette to the water shrew.

In 1896, Lydekker produced $A$ Handbook to the British Mammalia, a rather slight work that was in no way a forerunner to the present Handbook. He was able to add to his list the yellow-necked mouse which had been first recorded in Britain in 1894, and he recognized only one species of martin. Millais's large three-volume work of 1904, The Mammals of Great Britain and Ireland, with its careful documentation and lavish illustration gets less attention than it deserves. In fact, Millais set a high standard that culminated in a work that was to eclipse his own, namely, Barrett-Hamilton's History of British Mammals. Also, Millais added a new species to the British list by describing the Orkney vole. The History was an exhaustive compilation that appeared in successive parts between 1910 and 1921, covering bats, insectivores and rodents. Then it stopped and the projected parts on carnivores, deer and whales never appeared.

This is the heritage of The Handbook of British Mammals. It has embraced the knowledge but discarded the format of all these earlier works and appears as a fresh and stimulating publication; it is crammed with new informa. tion, and breaks new ground in its subject-matter and illustrations; and it has the backing of authority in the pooled resources of the Mammal Society of the British Isles. It is an excellently produced and scholarly achievement which, because the Society has subsidized it, can become a popular one too.

The Handbook is really two books in one: a systematie account of British mammals, and a guide to their general biology and study in the field. The systematic section is a masterly condensation of facts on the distribution, appearance, measurements, habitat, habits, reproduction, population, food, predators, and relations with man, of every species. There are eight more species than ninetoenthcentury writers had to cover, for there have since been introduced the grey squirrel, edible dormouse, coypu, mink, muntjac deer, sika deer and chinese water deer, and there is added the last but one indigenous mammal to be discovered - the Scilly shrew; in all, fifty-four terrestrial mammals. In addition, the common and grey seals are described and twenty-three species of whales. Every account has references to the main sources of information, and to Continental publications that give valuable informa. tion on the broader status of our species. It is admirably up to date in references to recent papers, including 1963.

The general section on populations and techniques pioneers a new field. There is no tradition of wild-life management studies in Britain, but this section indicates the problems involved and the ways in which fiold studies can be systematically approached. A section on museum techniques is included with, at last, definitions of 'greatest skull length', 'basal length', 'condylo-basal length', and other exasperating variables.

The book is a skilfully edited compilation of the work or notes of more than twenty authors. The Handbook took eight years to complete and the long delays that arise in collecting such a diversity of contributions are acknow. ledged by the editor, but at least no unfortunate member of the Mammal Society of the British Isles has had to be singled out for blame. Contrast Mr. Southern's praise of his co-authors with the unhappy straits of Thomas Bell in 1874, who had been so long delayed in producing the revised Quadrupeds that Bell wrote in his preface of the advantage of having $\mathrm{Mr}$. Tomes as co-author: "It is painful to be obliged to and that the extremely dilatory manner in which this advantage was bestowed, caused extreme uneasiness both to Mr. Van Voorst and to the author, and occasioned the lamented delay".

I see the Handbook as a vigorous publication that will not only go through several reprintings but will also be enthusiasticelly revised into new editions. There is no shortage of new information: the Handbook is full of personal communications and references to Ph.D. and D. Phil. theses, and this store of unpublished material is added to regularly in the Bulletin of the Mammal Society. Even since the Handbook has been published a new bat has been discovered to live in Britain, and perhaps feral reindeer will soon be added to the list.

The Handbook should, I think, be expanded. Chapters dealing generally with the distribution of Britain's mammals, their history, and relations with man would be most valuable, and with some courage a start might be made on distribution maps. The editor seems to have been uncertain what he should do about feral domestic animals and extinct species. On one hand, white cattle, feral goats and Soay sheep now find space only under sufferance, but deservo full treatment. On the other hand, brief accounts of selected extinct mammals, such as besver and wild boar, seem to have been included for no other reason than to satisfy long-standing tradition. But perhaps this is a misinterpretation and their inclusion does not signify a nostalgia for lost species so much as a reservation of space in anticipation of the time when they will be reinstated in Britain's nature reserves and national parks.
P. A. JEWEIL 